\title{
Association of methanogenic bacteria with ovine rumen ciliates
}

\author{
By C.K. STUMM, H.J.GIJZEN AND G. D. VOGELS \\ Department of Microbiology, Faculty of Science, University of Nijmegen, \\ 6525 ED Nijmegen, The Netherlands
}

(Received 6 April 1981-Accepted 6 August 1981)

\begin{abstract}
1. The frequency of association between methanogenic bacteria and ovine rumen ciliates was studied in the rumen fluid of a fistulated sheep.

2. A period of fasting and flushing of the rumen content with nitrogen resulted in a relatively high association, whereas the intake of food and flushing with hydrogen caused a detachment of the methanogenic bacteria from the ciliates.

3. The changes in the frequency of association can be correlated with the relative attribution to the $\mathbf{H}_{2}$ production by hydrogenogenic bacteria and rumen ciliates.
\end{abstract}

In the anaerobic environment of the rumen various nutritional interrelationships exist between bacteria and ciliates (Wolin, 1979; Prins \& Clarke, 1980). One of these interactions consists of the production of hydrogen by bacteria (Joyner et al. 1977) and ciliates (Abou Akkada \& Howard, 1960; Hungate, 1966; Prins \& Prast, 1973; Williams \& Harfoot, 1976) and the utilization of $\mathrm{H}_{2}$ as substrates for the production of methane by methanogenic bacteria (Hungate, 1967; Hungate et al. 1970). Recently Vogels et al. (1980) described a somatic association between methanogenic bacteria and several species of entodiniomorph ciliates from rumens of slaughtered cows. We now report the results of a study concerning methanogen-ciliate association in the rumen of a fistulated sheep under various circumstances of fasting and feeding.

MATERIALS AND METHODS

A Texel ram (body-weight $98 \mathrm{~kg}$ ) was provided with a rumen fistula. Rumen fluid was taken anaerobically by means of a water suction pump. The experiments were performed during the summer season and the sheep was kept on a pasture. Part of the samples were taken after the animal had been fasted for $14 \mathrm{~h}$ (during the night).

\section{Measurement of methane production}

Amounts of $3 \mathrm{ml}$ rumen fluid were injected anaerobically into $50 \mathrm{ml}$ bottles with $30 \mathrm{ml}$ liquid medium according to Clarke (1963) and a gas phase of nitrogen-carbon dioxide $(80: 20$, $\mathrm{v} / \mathrm{v}$ ) containing a small amount of ethane as the reference gas. The bottles were incubated in a New Brunswick G24 shaker at $190 \mathrm{rev}$. $/ \mathrm{min}$ and $39^{\circ}$. Every hour during a period of $4 \mathrm{~h}$ a gas sample was taken and the methane content was measured in a Pye Unicam GCV gas-liquid chromatograph. The methane production was calculated by the zero-time rate method (Hungate, 1966). The results were expressed as $1 \mathrm{CH}_{4}$ produced/l rumen fluid per $24 \mathrm{~h}$.

\section{Interaction of methanogenic bacteria with ciliates}

The methanogen-ciliate association was checked by means of Leitz epifluorescence microscopy as described earlier (Vogels et al. 1980) and is defined positive if at least twenty bacteria were attached to a ciliate cell. At least 100 ciliates were randomly checked in each rumen sample immediately after collection. Because Eudiplodinium maggii and Diplodinium dentatum were most numerous among the entodiniomorphs the values reported refer only to these two species. 


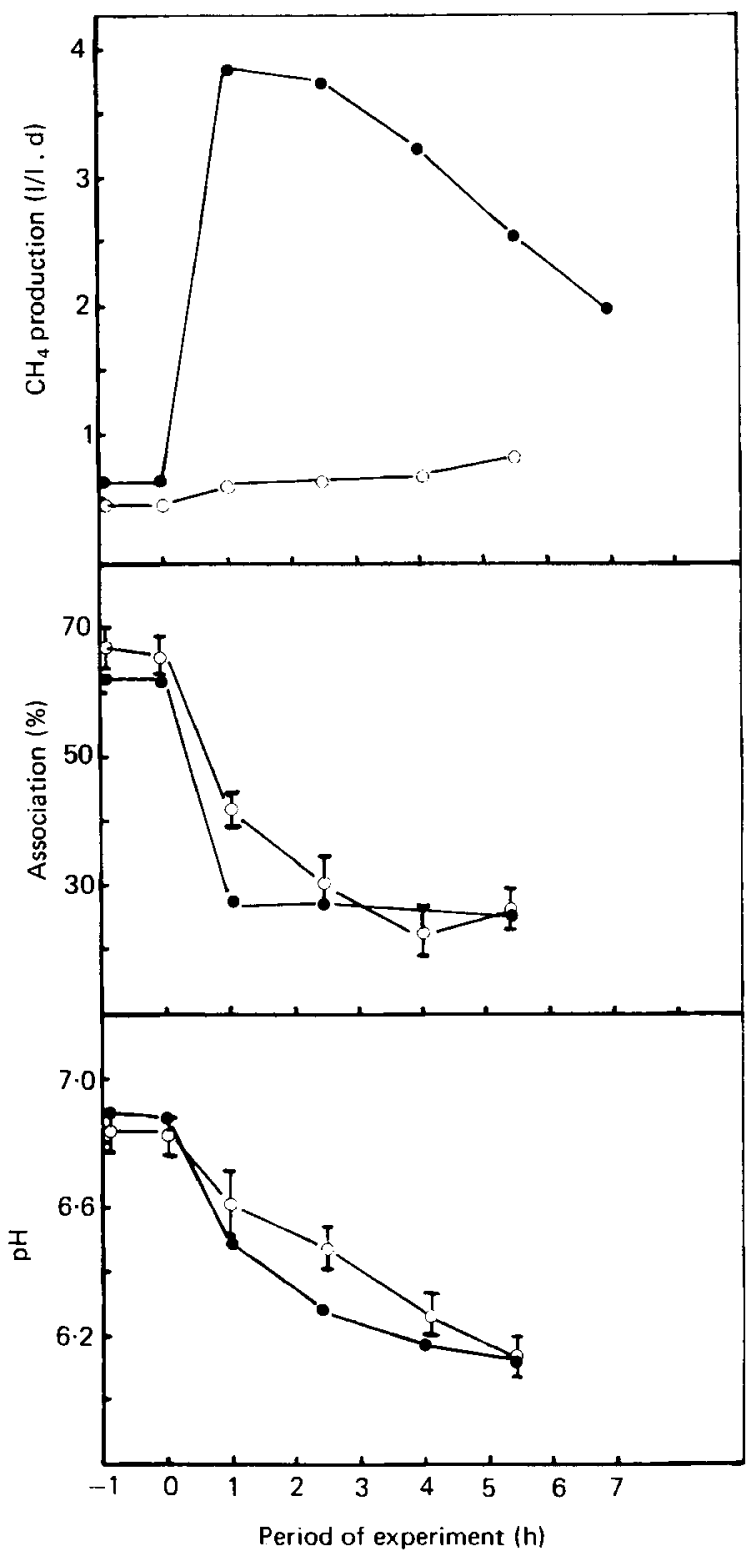

Fig. 1. Changes in methane production, frequency of association between methanogenic bacteria and ciliates and $\mathrm{pH}$ in samples of the sheep rumen. Samples were taken during and after a period of fasting for $14 \mathrm{~h}$. At $0 \mathrm{~h}$ the animal was allowed to graze $(\mathrm{O}$, mean values of three experiments) or it was given $1 \mathrm{~kg}$ pelleted food concentrate and thereafter allowed to graze $(\boldsymbol{O}$, one experiment). The standard errors of $\mathrm{CH}_{4}$ production are less than $0.017 \mathrm{l} / \mathrm{l}$ per $\mathrm{d}$ and are not inserted in the figure. 


\section{RESULTS}

The morphology of the methanogenic bacteria encountered in the sheep rumen and the association of methanogens with the ciliates were similar to those reported for cow rumens (Vogels et al. 1980): the methanogens in the fresh rumen fluid consisted of non-motile single rods, but those attached to the ciliates frequently grow as chains (Plate 1).

Two groups of experiments are reported here. In the first group some criteria were measured as a function of the nutrition of the animal, whereas in the second series the gas phase in the rumen was affected. The criteria examined were: methane production by a rumen sample as an indication of the substrate supply to the methanogenic bacteria at the time of sampling; association between methanogenic bacteria and ciliates in the collected sample as a measure of the interaction between both groups of micro-organisms; $\mathrm{pH}$ of the rumen at the time of sampling.

In the first series of experiments the ram received no food for a period of $14 \mathrm{~h}$ (during the night): two samples were withdrawn from the rumen, one at $1 \mathrm{~h}$ before the end, another at the end of this period. Then the animal was allowed to graze ad lib. and four more samples were taken (Fig. 1). Methane production was low during the period of fasting and gradually increased thereafter. The association changed strongly when food was taken by the animal: the percentage of ciliates covered with fluorescent bacteria decreased from approximately 65 to 25.

Methane production was strongly increased if the sheep received a meal of $1 \mathrm{~kg}$ pelleted food concentrate but the effect on the association was similar to that with grass, albeit more rapid. The changes of the association depended only on the feeding and not on diurnal rhythms as was apparent from studies in which the feeding regime was changed in time. The acidification observed during the digestion (Fig. 1) was not causally related to the decrease of association observed, since the association (approximately 65\%) in rumen samples taken at the end of the period of fasting was not altered by adjustment of the $\mathrm{pH}$ of the samples to values between 5.5 and 7.0 with $200 \mathrm{~mm}-2-[\mathrm{N}$-morpholino] ethane sulphonate buffer and further incubation for $1 \mathrm{~h}$ under an $\mathrm{N}_{2}-\mathrm{CO}_{2}(80: 20, \mathrm{v} / \mathrm{v})$ atmosphere at $39^{\circ}$. Moreover, a spontaneous drop in the $\mathrm{pH}$ values from 6.8 to 5.8 , which occurred on incubation of untreated samples for $4 \mathrm{~h}$ under an $\mathrm{N}_{2}-\mathrm{CO}_{2}$ atmosphere at $39^{\circ}$, did not lower the frequency of association; in fact, the association increased to a value of approximately $80 \%$

In the second series of experiments the same regime of fasting and feeding was applied but in situ measurements were performed. After a period of $2.5 \mathrm{~h}$, during which the sheep received grass ad lib. the rumen was flushed with $\mathrm{N}_{2}-\mathrm{CO}_{2}(80: 20, \mathrm{v} / \mathrm{v} ; 4 \mathrm{l} / \mathrm{min})$ through a 15 gauge syringe needle placed deeply in the rumen content. Care was taken to prevent entrance of air in the fistula. Flushing and feeding were continued for $2 \mathrm{~h}$ and samples were analysed in the usual way (Fig. 2). The gassing with $\mathrm{N}_{2}-\mathrm{CO}_{2}$ resulted in an increase of the frequency of association to the level of the starved rumen. In a control experiment performed in a similar way but with $\mathrm{H}_{2}-\mathrm{CO}_{2}(80: 20, \mathrm{v} / \mathrm{v} ; 41 / \mathrm{min})$ as the flushing gas a further decrease of the frequency of association was observed. Moreover, if the flushings in the rumen were performed for $2 \mathrm{~h}$ at the end of the $14 \mathrm{~h}$ fasting period and the animal was not allowed to take food, the treatment with $\mathrm{N}_{2}-\mathrm{CO}_{2}$ did not affect the association, but that with $\mathrm{H}_{2}-\mathrm{CO}_{2}$ resulted in a rapid decrease (Fig. 2).

\section{DISCUSSION}

Methane production by rumen samples was used in this study as a measure of the feeding condition of the ovine rumen and was compared with the frequency of association observed between methanogenic bacteria and rumen ciliates. Feeding with pelleted food concentrate resulted in a sixfold enhancement of methane production as compared to feeding with 


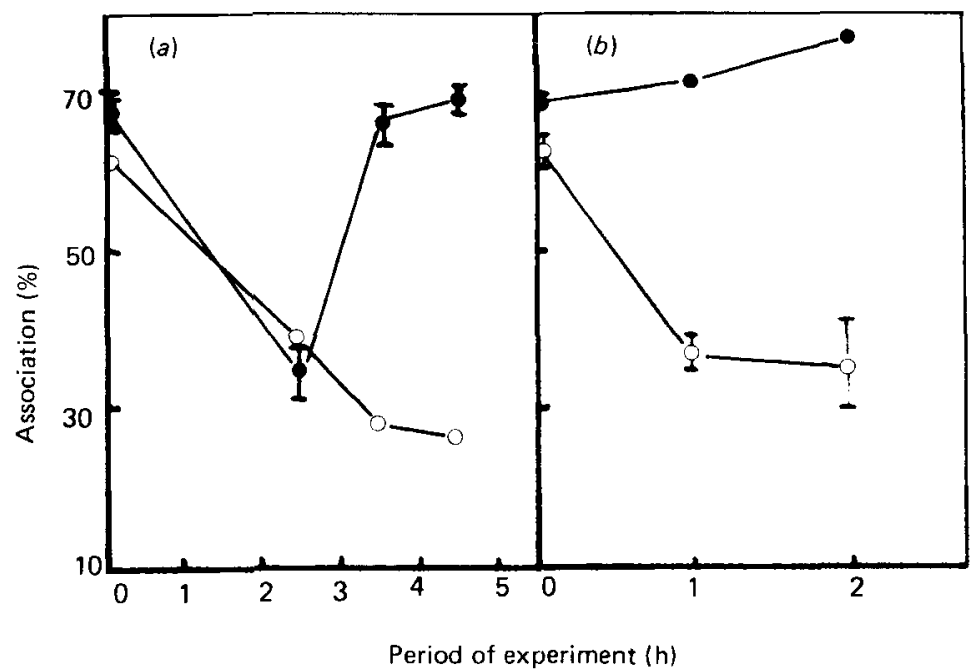

Fig. 2. Frequency of association between methanogenic bacteria and ciliates as affected by gassing in situ. (O), $\mathrm{N}_{2}-\mathrm{CO}_{2} ;(\mathrm{O}), \mathrm{H}_{2}-\mathrm{CO}_{2}$. A $14 \mathrm{~h}$ period of fasting ended at $0 \mathrm{~h}$. The gases were applied (a) after a $2.5 \mathrm{~h}$-period of grazing or (b) immediately after the end of the fasting period (right panel). The data represented with standard errors are mean values from three experiments.

meadow grass. As a result of feeding the metabolic activity of the rumen bacteria and ciliates is intensified and $\mathrm{H}_{2}$ and volatile fatty acids are produced; the production of $\mathbf{H}_{2}$ stimulates the activity of methanogenic bacteria. Czerkawski et al. (1972) showed that the amount of methane produced in vitro was directly proportional to the $\mathrm{H}_{2}$ concentration in the gas phase and that dissolved $\mathrm{H}_{2}$ was utilized very quickly.

The frequency of association between methanogenic bacteria and ciliates was most strong in samples taken from the fasting animal or from the rumen flushed with $\mathrm{N}_{2}-\mathrm{CO}_{2}$. The uptake of food into the rumen or flushing of the rumen of the fasting animal with $\mathrm{H}_{2}-\mathrm{CO}_{2}$ resulted in a low frequency of association and a detachment of the methanogenic cells from the ciliates.

Since the methanogenic bacteria participate in the digestion processes of the rumen by removing $\mathrm{H}_{2}$ produced by anaerobic bacteria and ciliates, the observed changes in the frequency of association may reflect the strength of the $\mathrm{H}_{2}$ sources in this ecosystem. On feeding or on flushing with $\mathrm{N}_{2}-\mathrm{CO}_{2}$ the rumen fluid is the stronger source; on exhaustion of the readily-accessible dissolved substrates various entodiniomorph ciliates become the relatively strong sources of $\mathrm{H}_{2}$, since they continue to degrade less-accessible plant materials.

It remains an open question by which mechanism(s) the rapid attachment and detachment of the non-motile methanogens to (and from) the ciliates is effected.

The ratio attached:non-attached methanogens was not measured because the number of attached bacteria cannot be determined easily; frequently the bacteria are grouped in patches on the surface of the ciliates. Rough estimates indicated that $10-20 \%$ of the methanogens were attached.

Care for the fistulated sheep and assistance in handling the animal by G. I. Derks are thankfully acknowledged. 


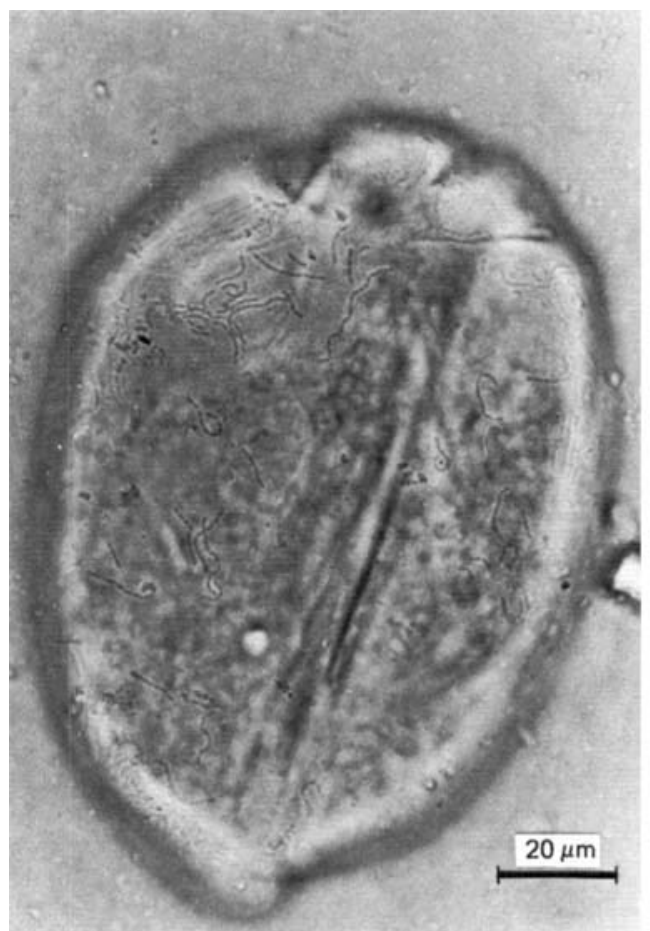

(a)

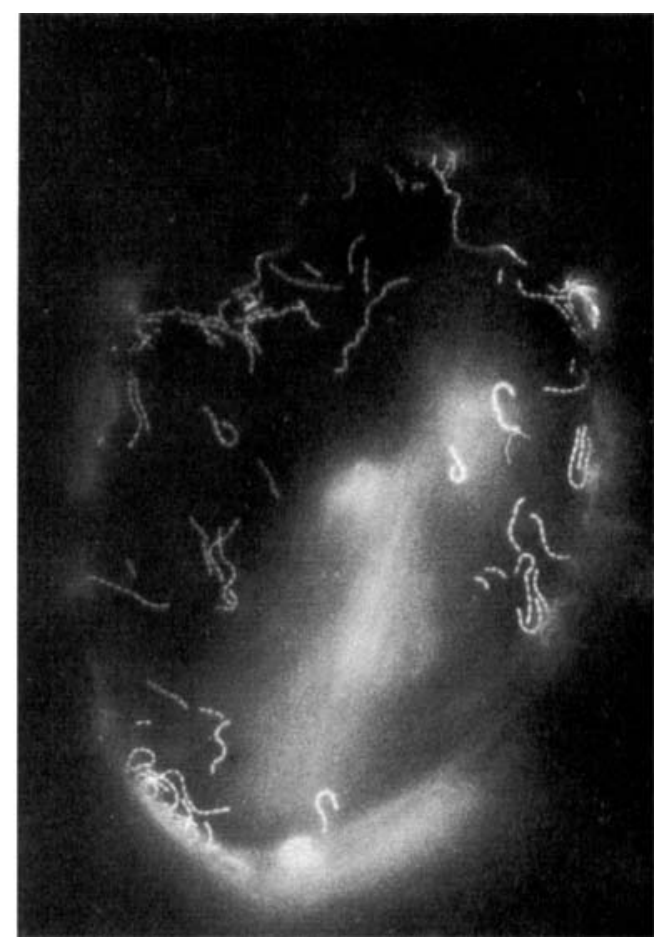

(b) 


\section{REFERENCES}

Abou Akkada, A. R. \& Howard, B. H. (1960). Biochem. J. 76, 445.

Clarke, R. T. J. (1963). J. gen. Microbiol. 33, 401.

Czerkawski, J. W., Harfoot, C. G. \& Breckenridge, G. (1972). J. appl. Bacteriol. 35, 537.

Hungate, R. E. (1966). The Rumen and its Microbes. New York: Academic Press.

Hungate, R. E. (1967). Arch. Mikrobiol. 59, 158.

Hungate, R. E., Smith, W., Bauchop, T., Yu, I. \& Rabinowitz, J. C. (1970). J. Bacteriol. 102, 389.

Joyner, A. E., Winter, W. T. \& Godboud, D. M. (1977). Can. J. Microbiol. 23, 346.

Prins, R. A. \& Clarke, R. T. J. (1980). In Digestive Physiology and Metabolism in Ruminants, p. 179 [Y. Ruckebusch and $P$. Thivend, editors]. Lancaster: MTP Press.

Prins, R. A. \& Prast, E. R. (1973). J. Protozool. 20, 471.

Vogels, G. D., Hoppe, W. F. \& Stumm, C. K. (1980). Appl. environ. Microbiol. 40, 608.

Williams, A. G. \& Harfoot, C. G. (1976). J. gen. Microbiol. 96, 125.

Wolin, M. J. (1979). In Advances in Microbial Ecology, vol. 3, p. 49 [M. Alexander, editor]. New York: Plenum Publishing Co.

\section{EXPLANATION OF PLATE}

Plate 1. A cell of Eudiplodinium maggii showing association with chains of methanogenic bacteria. (a), Bright field; (b), epifluorescence illumination. The bright, irregular shapes out of focus are ingested cell-wall fragments. 